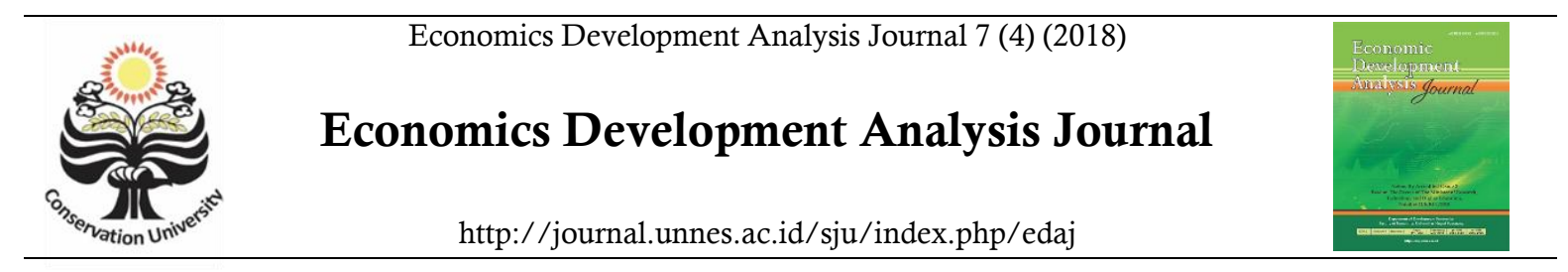

\title{
Implementasi Peraturan Daerah Kota Semarang Nomor 3 Tahun 2011
}

\section{Ardiyan Arif Kiswanto ${ }^{\bowtie}$}

Jurusan Ekonomi Pembangunan, Fakultas Ekonomi, Universitas Negeri Semarang

\section{Informasi Artikel Abstrak}

Sejarah Artikel

Diterima Juli 2018

Disetujui September 2018

Dipublikasikan Noember 2018

Keywords:

Implementasi, Perda, Deskriptif Persentase

\begin{abstract}
Tujuan dari penelitian ini adalah untuk menganalisis pelaksanaan Peraturan Daerah nomor 3 tahun 2011 tentang pajak hotel kategori usaha rumah kos di Kota Semarang khususnya di daerah Tembalang dan Gunungpati agar dapat berjalan lebih efektif. Metode yang digunakan dalam penelitian ini adalah metode deskriptif persentase. Responden dari penelitian ini adalah 100 wajib pajak aktif usaha rumah kos di daerah Tembalang dan Gunungpati. Hasil penelitian diketahui bahwa sejumlah 100 wajib pajak tidak bayar pajak disebabkan oleh adanya Peraturan Daerah yang masih belum jelas untuk pajak kos, eksistensi wajib pajak yang tinggi untuk menolak karena tarifnya dinilai terlalu tinggi, pemahaman tentang pajak kos yang masih kurang, kepatuhan wajib pajak yang masih kurang dalam menaati pajak kos, dan waktu dalam pembayaran pajak kos yang dinilai terlalu singkat.
\end{abstract}

\begin{abstract}
The purpose of this research is to analyze the implementation of local regulations number 3 year 2011 about hotel tax category business boarding houses within the city of Semarang especially in the Tembalang and Gunungpati in order to work more effective. The methodology that was used in this research was descriptive percentage method.Respondents from this research are 100 taxpayers active boarding house business in the Tembalang and Gunungpati. The results of the study it was discovered that a number of 100 taxpayers are not to pay tax caused by the presence of a regional regulation which it was not clear to tax boarding house, the existence of a high taxpayer to refuse because the rate is overvalued, an understanding of tax boarding is weak, taxpayer compliance is still lacking in compliance with boarding taxes, and the time in the tax payments of the board is considered too short.
\end{abstract}




\section{PENDAHULUAN}

UU nomor 28 tahun 2009 tentang Pajak Daerah dan Retribusi Daerah (PDRD) yang sebelumnya telah diubah beberapa kali telah berlaku sejak disahkan oleh DPR pada 18 Agustus 2009. Melalui UU PDRD, diharapkan dapat lebih mendorong peningkatan pelayanan kepada masyarakat dan kemandirian daerah. Pajak daerah dan retribusi daerah menjadi salah satu sumber pendapatan daerah yang penting guna membiayai pelaksanaan pemerintahan daerah. Pelaksanaan UU PDRD mengandalkan kemandirian daerah dalam mencari sumber pendapatan untuk daerahnya.

Pemerintah daerah diberikan kewenangan untuk menetapkan besaran tarif pajak daerah dalam batas tarif minimum dan maksimum sesuai koridor dalam UndangUndang. Pemerintah daerah dapat tidak memungut jenis pajak dan retribusi yang tercantum dalam undang-undang sesuai kebijakan pemerintahan daerah. Selain itu, Pemerintah Daerah dalam melakukan pungutan pajak harus tetap menempatkan pajak sesuai dengan fungsinya. Adapun fungsi pajak antara lain: 1). Fungsi budgeter yaitu bahwa pajak sebagai alat untuk mengisi kas negara yang digunakan untuk membiayai kegiatan pemerintahan dan pembangunan; 2). Fungsi regulator yaitu bahwa pajak dipergunakan sebagai alat mengatur untuk mencapai tujuan, misalnya: pajak ekspor dimaksudkan untuk mengekang pertumbuhan ekspor komoditi tertentu dalam rangka menghindari kelangkaan produk tersebut di dalam negeri. Mengingat begitu pentingnya peran PDRD dalam meningkatkan Pendapatan Asli Daerah (PAD), penguatan local taxing power kemudian dilakukan dengan berbagai cara, antara lain: menambah jenis pajak daerah dan retribusi daerah, memperluas basis pajak daerah dan retribusi daerah yang sudah ada, mengalihkan beberapa jenis pajak pusat menjadi pajak daerah, dan memberikan diskresi (keleluasaan) kepada daerah untuk menetapkan tarif. Disamping itu, tarif maksimum beberapa jenis pajak daerah juga dinaikkan untuk memberikan ruang gerak yang lebih fleksibel bagi daerah dalam melakukan pemungutan pajak daerah sesuai kebijakan dan kondisi daerahnya.

Berdasarkan UU nomor 28 Tahun 2009, penguatan local taxing power juga diberikan pada daerah propinsi yang memiliki diskresi atau kewenangan untuk menetapkan tarif pajak daerah dengan batasan tarif minimum dan maksimum. Pemberian kewenangan dalam penetapan tarif tersebut akan mempermudah daerah mengaitkan pengenaan tarif dengan tingkat pelayanan (the benefit tax link). Daerah dapat mendesain kebijakan tarif pajak untuk mencapai tujuan tertentu, seperti mengenakan tarif pajak yang tinggi untuk meningkatkan kualitas pelayanan, atau menurunkan tarif pajak untuk menarik investasi ke daerahnya. Dari pernyataan di atas sejalan dengan penelitian yang dilakukan oleh Berutu (2013) yang menyebutkan bahwa struktur tarif pajak yang lebih disukai (preferred tax rate structures) berpengaruh positif terhadap tingkat kepatuhan wajib pajak orang pribadi secara signifikan. Berbagai kondisi ideal yang menjadi tujuan dari pembentukan UU PDRD 2009 sebagaimana telah diuraikan di atas ternyata dalam prakteknya dan pengaturan operasional di daerah menghadapi berbagai hambatan sehingga dapat berdampak kepada pelaksanaan dan pembuatan peraturan daerah khususnya peraturan daerah Kota Semarang nomor 3 tahun 2011 tentang pajak hotel.

Salah satu bukti hambatan dalam pelaksanaan Peraturan Daerah dapat dibuktikan oleh penelitian yang dilakukan oleh Rachmawati dkk (2015) yang menjelaskan bahwa ada beberapa faktor yang menjadi penghambat penerapan pajak hotel kategori rumah kos tersebut antara lain; wajib pajak yang belum terdaftar, pemahaman, kepatuhan, keberatan tarif pajak, dan waktu. Faktor utama yang menghambat penerapan pajak hotel kategori rumah kos tersebut adalah waktu, karena banyak wajib pajak yang tidak mempunyai waktu untuk menyetorkan pajaknya sendiri setiap satu bulan. Hambatan yang sama juga dijelaskan oleh Afifah (2015), menurut afifah (2015) hambatan dari wajib 
pajak usaha rumah kos diantaranya adalah sosialisasi yang dilakukan oleh Dispenda Kota Malang masih belum maksimal, kesadaran untuk membayar pajak rumah kos yang kurang, akses untuk melakukan pembayaran pajak rumah kos yang terlalu jauh, dan sistem pembayaran yang masih manual. Untuk itu perlunya pengkajian ulang tekait peraturan pajak kos dengan besaran tarif yang sesuai dan penentuan kriteria objek pajak kos yang seharusnya tidak terbatas hanya pada kos yang memiliki jumlah kamar lebih dari sepuluh, tetapi juga biaya yang dikenakan perkamar. Aspek pelayanan merupakan salah satu aspek yang perlu dikaji ulang lebih dalam, sebab aspek pelayanan merupakan salah satu aspek yang menunjang keberhasilan suatu pelaksanaan pemungutan pajak kos. Hal tersebut dapat dibuktikan oleh penelitian yang dilakukan Supadmi (2012) yang menjelaskan bahwa tingkat kepatuhan dapat ditingkatkan dengan memberikan kualitas layanan yang lebih baik oleh kantor pajak, yang mencakup keamanan, kenyamanan, dan layanan cepat, serta penegakan hukum.

Tabel 1. Daftar Wajib Pajak (Aktif) Rumah Kos Tahun 2016

\begin{tabular}{clc}
\hline No & Daerah & Jumlah Kos \\
\hline 1. & Banyumanik & 12 \\
2. & Candisari & 1 \\
3. & Gajahmungkur & 4 \\
4. & Gayamsari & 28 \\
5. & Gunungpati & 333 \\
6. & Ngaliyan & 1 \\
7. & Pedurungan & 2 \\
8. & Semarang Barat & 33 \\
9. & Semarang Selatan & 10 \\
10. & Semarang Tengah & 4 \\
11. & Semarang Timur & 3 \\
12. & Tembalang & 140 \\
Jumlah & 571 \\
\hline
\end{tabular}

Sumber :DPKAD Kota Semarang, 2016

Tingkat kepatuhan wajib pajak dapat diukur dengan memeriksa apakah mereka mengerti hukum perpajakan, mengisi formulir pajak secara lengkap dan jelas, menghitung kewajiban perpajakan dengan benar, dan melaporkan kewajiban perpajakan tepat waktu.Semua bukti penelitan terdahulu yang menjadi hambatan dalam pelaksanaan peraturan daerah khususnya untuk pajak kos yang terjadi di atas juga dapat dibuktikan oleh salah satu kasus yang terjadi pada kepatuhan wajib pajak usaha rumah kos di Kota Semarang pada tabel 1 tersebut.

Tabel di atas merupakan wajib pajak aktif yang terdapat di wilayah Kota Semarang. Dari data diatas menjelaskan bahwa daerah yang memiliki jumlah wajib pajak terbanyak terdapat di Daerah Gunungpati dan Tembalang. Hal tersebut sangat realistis mengingat di kawasan tersebut terdapat Universitas Negeri ternama yang pasti sangat menarik minat bagi para pelajar lulusan SMA dari dalam maupun luar Kota Semarang untuk mendaftar. Namun, dengan banyaknya jumlah wajib pajak yang terdaftar aktif tidak berbanding lurus dengan jumlah pembayar pajak. Hal tersebut dapat dibuktikan dengan data wajib pajak aktif rumah kos tahun 2016 di Kota Semarang yang terdapat tabel 2 .

Data di atas dapat dijelaskan bahwa jumlah wajib pajak aktif usaha rumah kos di Kota Semarang memiliki total keseluruhan sebesar 571 Wajib pajak. Dari 571 wajib pajak yang terdaftar, sejumlah 85 wajib pajak aktif yang taat bayar pajak dan 486 waijb pajak yang belum membayar pajak. Dari total wajib pajak yang belum membayar pajak didominasi oleh wilayah Tembalang dan Gunungpati. Maka dari itu, dengan rendahnya tingkat partisipasi wajib pajak rumah kos didaerah Gunungpati dan Tembalang membuat penulis melaksanakan penelitian lebih lanjut untuk mengetahui berbagai macam kendala dan keluhan wajib pajak rumah kos dalam membayar pajak kos. Selain itu juga, berbagai upaya dalam bentuk kegiatan yang dilakukan oleh pemerintah daerah untuk meningkatkan tingkat partisipasi wajib pajak dalam membayar pajak kos khususnya di wilayah Tembalang dan Gunungpati. Hal tersebut dapat dibuktikan dengan adanya sosialisasi dalam rangka optimalisasi penerimaan pajak, Kanwil DJP 
Jawa Tengah I bekerja sama dengan Pemerintah Kota Semarang dan Bank Jateng mengadakan talkshow peluang permodalan usaha kos dan edukasi perpajakan pada Sabtu (28/05). Sekitar 150 pengusaha kos di Kecamatan Tembalang dan Kecamatan Gunungpati diundang dalam kegiatan yang berlangsung di aula Kantor Pusat
Bank Jateng dan menghadirkan narasumber Indra Wardhana, Kepala Seksi Ekstensifikasi Kantor Pelayanan Pajak (KPP) Pratama Semarang Candisari, Setiadi dari Bank Jateng, serta Agus Wuryanto, Kepala Bidang Pajak DPKAD Kota Semarang (Dirjen Pajak Kementrian Keuangan, 2016).

Tabel 2. Daftar Wajib Pajak (Aktif) Rumah Kos Tahun 2016

\begin{tabular}{|c|c|c|c|c|}
\hline No & Wilayah & $\begin{array}{l}\text { Total yang } \\
\text { sudah bayar }\end{array}$ & Total yang belum bayar & Total keseluruhan \\
\hline 1. & Banyumanik & 6 & 6 & 12 \\
\hline 2. & Candisari & 1 & - & 1 \\
\hline 3. & Gajahmungkur & 1 & 3 & 4 \\
\hline 4. & Gayamsari & 3 & 25 & 28 \\
\hline 5. & Gunungpati & 25 & 308 & 333 \\
\hline 6. & Ngaliyan & 1 & - & 1 \\
\hline 7. & Pedurungan & 1 & 1 & 2 \\
\hline 8. & Semarang Barat & 5 & 28 & 33 \\
\hline 9. & Semarang Selatan & 5 & 5 & 10 \\
\hline No & Wilayah & $\begin{array}{l}\text { Total yang } \\
\text { sudah bayar }\end{array}$ & Total yang belum bayar & Total keseluruhan \\
\hline 10. & Semarang Tengah & 4 & - & 4 \\
\hline 11. & Semarang Timur & 1 & 2 & 3 \\
\hline 12. & Tembalang & 32 & 108 & 140 \\
\hline \multicolumn{2}{|c|}{ Jumlah } & 85 & 486 & 571 \\
\hline
\end{tabular}

Sumber : DPKAD Kota Semarang, 2016

Sehubungan dengan masalah yang terjadi di lapangan terkait wajib pajak rumah kos yang telat bayar. Selain itu juga, permasalahan yang terjadi terhadap pelaksanaan peraturan daerah Kota Semarang nomor 3 tahun 2011 tentang pajak hotel khususnya untuk kategori usaha rumah kos yang bersumber dari permasalahan implementasi UU nomor 28 Tahun 2009 yang kurang efektif sehingga membuat peneliti tertarik untuk melakukan penelitian di Kota Semarang dengan tujuan untuk mengetahui secara langsung mengenai implementasi Peraturan Daerah Kota Semarang nomor 03 tahun 2011 tentang pajak hotel kategori usaha rumah kos (studi kasus di wilayah Tembalang dan Gunungpati).

\section{METODE PENELITIAN}

Penelitian ini menggunakan dua jenis data yaitu data primer dan sekunder. Data primer dalam penelitian ini diperoleh dengan cara melakukan observasi,dokumentasi, wawancara, kuesioner, dan Focus Group Discussion (FGD). Data sekunder yang digunakan dalam penelitian ini diperoleh dari instansi terkait, seperti Badan Pendapatan Daerah (BAPENDA) Kota Semarang. Lokasi penelitian yaitu terletak di Kota Semarang khususnya di wilayah Tembalang dan Gunungpati dengan melibatkan 100 wajib pajak. Penentuan 100 wajib pajak mengacu kepada rumus penentuan proporsi sampel 
wilayah menurut slovin yang telah dihitung pembagiannya per wilayah seperti di bawah ini,

Sub populasi $=$ populasi $\mathrm{x}$ sampel (jumlah sub populasi dibagi populasi dikali sampel) Fokus dalam penelitian ini yaitu menganalisis pelaksanaanperaturan Daerah Kota Semarang Nomor 3 Tahun 2011 tentang pajak hotel kategori usaha rumah kos. Metode analisis yang digunakan yaitu kualitatif deskriptif persentase dengan menggunakan skala guttman sebagai pengukuran kuesioner. Sebelum kuesioner disebar oleh peneliti ke lapangan, peneliti terlebih dahulu melakukan uji coba kuesioner. Uji coba kuesioner tersebut nantinya akan diuji menggunakan uji validitas dan reliabilitas. Kegunaan dari Uji Validitas dan Reliabilitas untuk menentukan valid tidaknya suatu instrumen dalam melakukan penyebaran kuesioner ke lapangan. Uji Validitas untuk tipe jenis skala guttman menggunakan rumus koefisien reprodusibilitas dan koefesien skalabilitas.

Rumus koefisien reprodusibilitas:

$\mathrm{Kr}=1-\mathrm{e} / \mathrm{n}$

Dimana:

$$
\begin{aligned}
\mathrm{Kr} & =\text { Koefisien reprodusibilitas } \\
\mathrm{e} & =\text { nilai eror } \\
\mathrm{n} & =\text { total kemungkinan jawaban, yaitu } \\
& \text { jumlah pertanyaan } \mathrm{x} \text { jumlah } \\
& \text { responden }
\end{aligned}
$$

Rumus koefisien skalabilitas:

$\mathrm{Ks}=1-(\mathrm{e} / \mathrm{x})$

Dimana:

$$
\begin{aligned}
\mathrm{Ks} & =\text { Koefisien skalabilitas } \\
\mathrm{e} & =\text { Nilai eror } \\
\mathrm{x} & =\text { Jumlah kesalahan yang diharapkan = } \\
& \mathrm{c}(\mathrm{n}-\mathrm{Tn}) \text { dimana } \mathrm{c} \text { adalah } \\
& \text { kemungkinan mendapatkan jawaban } \\
& \text { yang benar atau sama dengan } \mathrm{C}=0,5 \\
\mathrm{n} \quad & \text { jumlah total pilihan jawaban } \\
& \text { jumlah pertanyaan } \mathrm{x} \text { jumlah } \\
& \text { responden }
\end{aligned}
$$

Tn =Jumlah pilihan jawaban

Tabel 3 ini merupakan indeks Uji Validitas yang dikemukakan oleh Guilford
(1956) yang diklasifikasikan berdasarkan tingkat validitas. Indeks uji validitas menurut Guilford (1956) ini nantinya dapat digunakan sebagai patokan kesiapan kuesioner untuk disebar ke lapangan:

Tabel 3. Indeks Uji Validitas Guilford

\begin{tabular}{lll}
\hline Tingkat Validitas & Kriteria \\
\hline $0,81<$ rxy & 1,00 & sangat tinggi (sangat baik) \\
$0,61<$ rxy $\quad 0,80$ & tinggi (baik) \\
$0,41<$ rxy $\quad 0,60$ & sedang (cukup) \\
$0,21<$ rxy $\quad 0,40$ & rendah (kurang) \\
$0,00<$ rxy $\quad 0,20$ & sangat rendah (jelek) \\
rxy $\quad 0,00$ & & tidak valid \\
\hline
\end{tabular}

Sumber: Guilford, 1956

Instrumen yang reliabel adalah instrumen yang bila digunakan beberapa kali untuk mengukur objek yang sama akan menghasilkan data yang sama.

Dengan menggunakan instrumen yang valid dan reliabel dalam pengumpulan data, maka diharapkan hasil penelitian akan menjadi valid dan reliabel. Uji reliabilitas baik untuk skala Guttman yang dihitung dengan menggunakan program SPSS. Untuk menentukan kriteria indeks reliabilitas adalah sebagai berikut:

Tabel 4. Indeks Uji Reliabilitas Guilford

\begin{tabular}{ll}
\hline Tingkat Reliabilitas & Kriteria \\
\hline $0,81-1,00$ & Sangat Reliabel \\
$0,61-0,80$ & Reliabel \\
$0,41-0,60$ & Cukup Reliabel \\
$0,21-0,40$ & Agak Reliabel \\
$0,00-0,20$ & Kurang Reliabel \\
\hline
\end{tabular}

Sumber: Guilford, 1956

\section{HASIL DAN PEMBAHASAN}

Rumus penentuan proporsi sampel wilayah menurut slovin yang telah dihitung pembagiannya per wilayah diperoleh jumlah pembagian sampel seperti yang terdapat pada tabel 5 tersebut, 
Tabel 5. Perhitungan penentuan proporsi sampel

\begin{tabular}{llll}
\hline No & Wilayah & Populasi & Sampel \\
\hline 1 & Gunungpati & 333 & 70 \\
2. & Tembalang & 140 & 30 \\
\multicolumn{2}{l}{ Total } & 473 & 100 \\
\hline
\end{tabular}

Sumber: Data primer diolah, 2017

Setelah menentukan jumlah sampel, peneliti membagikan kuesioner kepada responden yang tergolong sebagai wajib pajak usaha rumah kos aktif sebanyak 70 responden di daerah Gunungpati dan 30 di daerah Tembalang.Cara Dibawah ini merupakan hasil dari koefesien reprodusibilitas dan koefisien skalabilitas:

D1

$\begin{array}{ll}\text {-Jumlah butir } & : 19 \\ \text {-Jumlah potensi eror } & : \text { Jumlah butir *Ukuran } \\ \text { sampel } & : 19 * 100=1900 \\ \text {-Ukuran Sampel } & : 100 \\ \text {-Eror } & : 254 \\ \text { D2 } & \text {-Koefisien reprodusibilitas? } \\ & \text { - Koefisien skalabilitas? } \\ \text { D3 }\end{array}$

\section{Koefesien reprodusibilitas}

$\mathrm{Kr}=1-$ (eror/jumlah potensi eror)

$\mathrm{Kr}=1-(254 / 1900)$

$\mathrm{Kr}=1-(0,1336)$

$\mathrm{Kr}=\mathbf{0 , 8 6 6 3}$

Jadi, koefesien reprodusibilitas menurut skala guttmanuntuk kuesioner wawancara wajib pajak terkait implementasi peraturan daerah Kota Semarang nomor 3 tahun 2011 tentang pajak hotel kategori usaha rumah kos adalah sebesar 0,8663. Menurut indeks Guilford (1956) kuesioner diterima karena memiliki nilai yang sangat baik atau sangat tinggi.

\section{Koefisien skalabilitas}

$\mathrm{Ks}=1-(\mathrm{eror} /(0,5 *$ jumlah potensi eror $))$

$\mathrm{Ks}=1-\left(254 /\left(0,5^{*} 1900\right)\right.$

$\mathrm{Ks}=1-(254 / 950)$

$\mathrm{Ks}=1-(0,2673)$

$\mathrm{Ks}=\mathbf{0 , 7 3 2 6}$

Jadi, koefesien skalabilitas menurut skala guttmanuntuk kuesioner wawancara wajib pajak terkait implementasi peraturan daerah Kota Semarang no 3 tahun 2011 tentang pajak hotel kategori usaha rumah kos adalah sebesar 0,7326. Menurut indeks Guilford (1956) kuesioner diterima karena memiliki nilai yang baik atau tinggi.

Dibawah ini merupakan hasil dari reliabilitas skala guttman dengan menggunakan SPSS:

\section{Reliability Statistics}

\section{Cronbach's \\ Alpha Based on}

Cronbach's Standardized

Alpha Items $\quad \mathrm{N}$ of Items

\begin{tabular}{lll}
\hline, 923 & ,924
\end{tabular}

Gambar 1. Hasil analisis skala guttman

Sumber: data output diolah menggunakan SPSS, 2017

Tampilan output SPPS di atas menunjukkan bahwa konstruk implementasi Peraturan Daerah Kota Semarang memberikan nilai Cronbach Alpha sebesar 92,4\% yang menurut kriteria Guilford (1956) sangat reliabel. Hal ini mengindikasikan bahwa responden menjawab pertanyaan dengan konsisten.

Penelitian ini menggunakan analisis kualitatif deskriptif persentase untuk mengetahui bagaimana kondisi dari implementasi Peraturan Daerah Kota Semarang nomor 3 tahun 2011 tentang pajak hotel kategori usaha rumah kos termasuk dengan permasalahan-permasalahan yang menjadi hambatannya. Cara untuk melihat dan meneliti hambatan atau kendala-kendala yang dihadapi oleh wajib pajak wilayah Gunungpati dan Tembalang dalam proses pembayaran pajak kos maka peneliti mengikuti program FGD (Focus Group Discussion) di wilayah Gunungpati. Proses pelaksanaan FGD dihadiri oleh wajib pajak, Ketua RT, dan beberapa perangkat dari kelurahan di Sekaran. Selama pelaksanaan FGD tersebut, peneliti mendapatkan 32 Responden. Jumlah 32 Responden tersebut menghasilkan berbagai macam pendapat mengenai kendala-kendala yang dihadapi oleh wajib pajak terhadap Peraturan Daerah Kota 
Semarang nomor 3 tahun 2011 tentang pajak hotel khususnya pajak kos yang termasuk didalamnya. Kuesioner tersebut berisi pandangan bagaimana kinerja dari Petugas Pajak, Bagaimana sistem dalam pelaksanaan peraturan, dan membahas mengenai kendala wajib pajak terhadap isi dari Peraturan Daerah tersebut. Selain dari faktor FGD, peneliti juga menyebar kuesioner kepada wajib pajak yang telah bayar dengan yang tidak bayar sesuai kriteria peneliti yang terdapat di Wilayah Gunungpati dan Tembalang. Data Wajib Pajak aktif tersebut didapatkan oleh peneliti melalui pihak dari BAPENDA Kota Semarang.

Proses pengembangan dan peningkatan suatu sektor masih memiliki berbagai macam faktor yang menjadi kendala atau penghambat, tak terkecuali pada penerapan pajak hotel khususnya pajak kos. Untuk mencapai tujuan dari setiap program pengembangan yang sudah direncanakan, beberapa faktor yang menjadi penghambat harus dapat diatasi dan di minimalisir. Untuk mengatasi hamabatanhambatan tersebut diperlukan peran aktif dari semua bagian baik itu dari segi pemerintahan seperti pembuat kebijakan, petugas pajak, maupun subjek dan objek pajak. Berikut adalah beberapa hambatan dalam implementasi peraturan daerah Kota Semarang nomor 3 tahun 2011 tentang pajak hotel kategori usaha rumah kos:

Peraturan Daerah merupakan kunci dasar dari pelaksanaan suatu pemungutan Pajak Daerah. Penyusunan suatu peraturan daerah khususnya untuk pajak kos ini banyak sekali hal-hal yang perlu diperhatikan. Mulai dari Tarif dasar yang dikenakan untuk wajib pajak kos, kriteria rumah kos yang kena pajak kos, tata cara pembayaran dan pengisian, hingga sanksi atau denda yang dikenakan wajib pajak kos jika telat dalam melakukan pembayaran sesuai jatuh tempo yang telah ditetapkan.

Selain itu, dalam menyusun peraturan daerah yang baru memerlukan jangka waktu dan proses penyusunan yang lama yang melewati berbagai macam proses penggodokan.Selain itu, untuk pajak kos tergolong masih dalam ruang lingkup pajak hotel yang memiliki berbagai macam perbedaan seperti objek, pengkategorian, dan juga sistem penyewaan tempat. Sehingga hal tersebut membuat wajib pajak merasa keberatan untuk membayar pajak kos yang memiliki tarif dasar pengenaan yang sama dengan pajak hotel yang tergolong kedalam kategori yang tinggi dan memberatkan.

Selain melihat dari sudut pandang pendapat dari petugas BAPENDA Kota Semarang, peneliti juga berupa untuk melihat dari sudut pandang wajib pajak dalam menanggapi Peraturan Daerah Kota Semarang. Berikut gambar 2 yang merupakan pie chart kesesuaian PERDA Kota Semarang nomor 3 tahun 2011 tentang pajak hotel terhadap syarat yuridis.

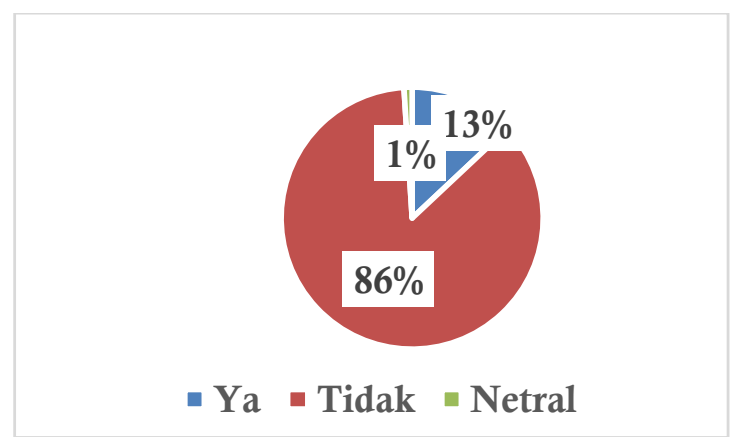

Gambar 2.Pie Chartkesesuaian PERDA Kota Semarang nomor 3 tahun 2011 tentang pajak hotel terhadap syarat yuridis

Sumber: Data primer diolah, 2017

Data di atas dapat dijelaskan bahwa mayoritas memilih bahwa PERDA Kota Semarang nomor 3 tahun 2011 tentang pajak hotel belum sesuai dengan kaidah syarat yuridis. Data menyebutkan sebesar $86 \%$ wajib pajak tidak menyetujui adanya syarat yuridis di tubuh PERDA Kota Semarang. Data 86\% tersebut berasal dari 63 wajib pajak yang berasal dari Gunungpati dan 23 yang berasal dari Tembalang. Selain itu, terdapat wajib pajak yang merasa bahwa PERDA Kota Semarang nomor 3 tahun 2011 tentang pajak hotel ini sudah sesuai dengan syarat yuridis. Dari data di atas terdapat sebesar 13\% yang berasal dari 6 wajib pajak di daerah Gunungpati dan 7 wajib pajak yang berasal dari daerah Tembalang. 
Selain itu juga terdapat wajib pajak yang berasal dari Gunungpati yang lebih kearah netral dengan jumlah 1 wajib pajak.

Selain meneliti PERDA Kota Semarang nomor 3 tahun 2011 tentang pajak hotel melalui syarat yuridis. Peneliti juga meneliti dari segi syarat keadilan. Disini merupakan gambar 3 yang merupakan pie chart pendapat dari wajib pajak terhadap kesesuaian PERDA Kota Semarang nomor 3 tahun 2011 tentang pajak hotel terhadap syarat keadilan.

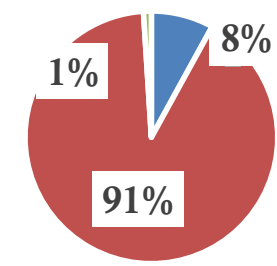

$$
\text { - Ya - Tidak } \text { - Netral }
$$

Gambar 3. Pie Chartkesesuaian PERDA Kota Semarang nomor 3 tahun 2011 tentang pajak hotel terhadap syarat keadilan

Sumber: Data primer diolah, 2017

Data di atas dapat dijelaskan bahwa mayoritas wajib pajak memandang bahwa PERDA Kota Semarang nomor 3 tahun 2011 tentang pajak hotel belum sesuai dengan kaidah syarat keadilan. Data menyebutkan sebesar $91 \%$ wajib pajak tidak menyetujui adanya syarat keadilan di dalam tubuh PERDA Kota Semarang. Data 91\% tersebut berasal dari 63 wajib pajak yang berasal dari Gunungpati dan 28 yang berasal dari Tembalang. Selain itu, terdapat wajib pajak yang merasa bahwa PERDA Kota Semarang nomor 3 tahun 2011 tentang pajak hotel ini sudah sesuai dengan syarat keadilan. Data di atas terdapat sebesar $8 \%$ yang berasal dari 6 wajib pajak di daerah Gunungpati dan 2 wajib pajak yang berasal dari daerah Tembalang. Selain itu juga, terdapat wajib pajak yang berasal dari Gunungpati yang lebih kearah netral dengan jumlah 1 wajib pajak.

Selain meneliti PERDA Kota Semarang nomor 3 tahun 2011 tentang Pajak Hotel melalui syarat keadilan. Peneliti juga meneliti dari segi syarat ekonomi. Dibawah ini adalah merupakan pie chart pendapat dari wajib pajak terhadap kesesuaian PERDA Kota Semarang nomor 3 tahun 2011 tentang pajak hotel terhadap syarat ekonomi.Data pie chartpada gambar 4 dapat dijelaskan bahwa untuk pengusaha kos yang merasa bahwa PERDA Kota Semarang tentang pajak hotel belum sesuai dengan syarat ekonomi adalah sebesar $82 \%$. Besaran $82 \%$ tersebut, diperoleh dari jumlah wajib pajak kos untuk daerah Gunungpati sebesar 64 dan 18 untuk daerah Tembalang. Sementara untuk data persentase yang setuju dengan kesesuaian PERDA Kota Semarang dengan syarat ekonomi adalah sebesar $17 \%$ yang berasal dari 5 wajib pajak di daerah Gunungpati dan 12 wajib pajak di daerah Tembalang. Untuk data $1 \%$ netral berasal dari wajib pajak yang terdapat di Gunungpati.

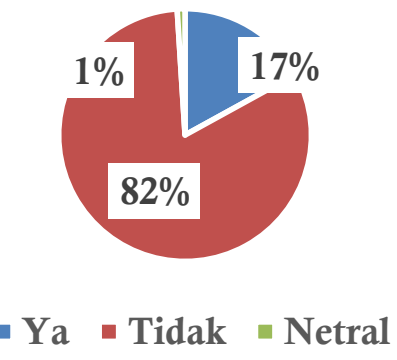

Gambar 4.Pie Chartkesesuaian PERDA Kota Semarang nomor 3 tahun 2011 tentang Pajak Hotel terhadap syarat ekonomi

Sumber: Data primer diolah, 2017

Jumlah besarnya tarif pajak yang dikenakan dari Subjek Pajak adalah 10\% (sepuluh persen), maka setiap penghasilan yang didapatkan dari persewaan wajib dikenakan Pajak Penghasilan yang besarnya 10\% (sepuluh persen) dan untuk pembayarannya jatuh tempo

pada tanggal 10 sesuai dengan Peraturan Daerah Kota Semarang. Dari hasil wawancara ketentuan besaran tarif tersebut, membuat banyak pengusaha rumah kos mengeluh karena merasa keberatan dengan tarif yang telah 
ditetapkan sebesar $10 \%$. Mereka beranggapan bahwa rumah kos tidak bisa disetarakan dengan hotel yang mempunyai fasilitas mewah. Mereka mengaku bahwa penghasilan mereka tidak besar untuk usaha rumah kos ini, jika membayar pajak sebesar $10 \%$ per bulan, berapa lagi keuntungan yang mereka dapatkan. Mereka mengharapkan pemerintah daerah dapat mengkaji ulang mengenai besaran tarif tersebut. Hal tersebut dapat dibuktikan pada gambar 5 data pie chart kuesioner menurut pendapat dari wajib pajak terhadap PERDA yang telah peneliti lakukan di daerah Gunungpati dan Tembalang.

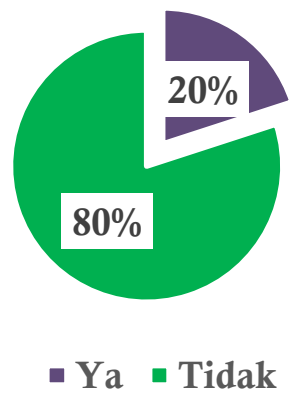

Gambar 5.Pie Chartarif pajak $10 \%$ sesuai dengan asas keadilan dan keringanan untuk wajib pajak

Sumber: Data primer diolah, 2017

Data di atas menyebutkan bahwa terdapat sebesar $80 \%$ wajib pajak menilai tarif pajak $10 \%$ belum sesuai dengan asas keadilan dan keringanan untuk wajib pajak. Data $80 \%$ itu berasal dari wajib pajak wilayah Gunungpati dengan jumlah 62 dan 18 untuk wilayah Tembalang. Sementara untuk nilai $20 \%$, itu berasal dari 8 wajib pajak Gunungpati dan 12 wajib pajak dari Tembalang.

Selain itu juga, berbagai macam pendapat yang berasal dari wajib pajak salah satunya di daerah Gunungpati. Wajib pajak mengeluhkan karena tarif pajak yang terlalu tinggi, tidak sesuai karena telalu banyak sehingga pelaku kos kehabisan pendapatan karena untuk keperluan lain, terlalu mahal untuk pajak kos, terlalu tinggi sementara pendapatan kos tidak menentu, kos sepi, karena kos di daerah Sekaran belum bisa dijadikan sebagai bentuk usaha, tergantung kemampuan pemilik kos (kebutuhan semakin tinggi dan batas pelunasan kos sering mundur), perlu kategori jenis kos dan banyak anak kos, penghasilan kos per bulan tidak pasti, dan karena penerimaan kos yang berasal dari kamar sedikit berbeda dengan kos yang memiliki kamar banyak. Selain itu juga, terdapat pandangan positif dan membangun dari wajib pajak wilayah Gunungpati seperti dengan adanya pajak hotel untuk rumah kos akan menambah pendapatan daerah dan kalau bisa tarif pajak nya $5 \%$.

Selain pendapat dari wajib pajak yang berasal dari Gunungpati, juga terdapat pendapat dari wajib pajak Tembalang seperti tarif yang memberatkan, pendataan harus merata, dan wajib pajak ada yang sudah membayar pajak kos melalui $\mathrm{Pph}$ final yang nanti jumlah pendapatan akan diterima oleh Pemerintah Pusat bukan Pemerintah Daerah. Pajak rumah kos, seharusnya mempunyai peraturan yang berdiri sendiri dan tidak disetarakan dengan hotel. Sehingga tarifnya bisa disesuaikan dan para wajib pajak bisa lebih menerima karena usaha rumah kos tersebut tidak disetarakan dengan pajak hotel.

Pemahaman wajib pajak terhadap peraturan perpajakan adalah cara wajib pajak dalam memahami peraturan perpajakan yang telah ada. Wajib pajak yang tidak memahami peraturan perpajakan secara jelas cenderung akan menjadi wajib pajak yang tidak taat. Pengusaha rumah kos memiliki alasan mengapa ia tidak mendaftarkan usahanya, alasannya antara lain ia takut bahwa uang pajak yang ia bayarkan akan dikorupsi oleh petugas pajak serta ia tidak tahu dan tidak paham mengenai jenis pajak ini. Umumnya masyarakat masih sinis dan kurang percaya terhadap keberadaan pajak karena masih merasa sama dengan upeti, memberatkan, pembayarannya sering mengalami kesulitan, ketidak mengertian masyarakat apa dan bagaimana pajak serta kesulitan dalam menghitung dan melaporkannya.

Manfaat pajak yang dapat kita rasakan yaitu dengan pajak, uang yang kita bayarkan 
kepada negara akan digunakan oleh negara untuk kebutuhan seluruh rakyat Indonesia. Seharusnya para wajib pajak diberi pemahaman yang lebih mengenai manfaat pajak dan arah uang pajak akan diguanakan melalui sosialisasi, dan dilakukan pendekatan terhadap wajib pajak agar para wajib pajak lebih merasa dekat dan tidak takut membayar pajak.

Selain dengan adanya pemahaman dan pendapat dari wajib pajak, hal tersebut juga didukung oleh data baik itu data seputar pengetahuan dan berbagai macam pendapat mengenai pajak kos yang dijelaskan melalui pie chart. Dibawah ini merupakan pie chart pengusaha kos yang mengetahui bahwa terdapat pajak untuk rumah kos yang lebih dari 10 kamar.

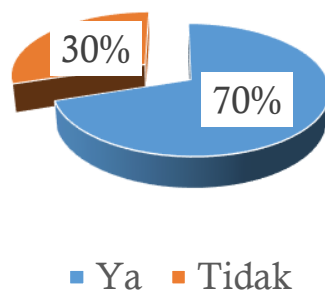

Gambar 6.Pie Chart Pengusaha Kos mengetahui terdapat pajak untuk rumah kos lebih dari 10 kamar

Sumber: Data primer diolah, 2017

Pengusaha kos yang mengetahui bahwa kamar kos yang lebih dari 10 kamar dikenakan pajak sebesar $10 \%$ adalah sejumlah $70 \%$, dari data 70\% tersebut berasal dari 43 Pengusaha kos yang berasal dari Gunungpati dan 27 dari Pengusaha kos di Tembalang. Sementara untuk pengusaha kos yang tidak mengetahui bahwa kamar kos yang lebih dari 10 kamar dikenakan pajak sebesar $10 \%$ adalah sejumlah $30 \%$, jumlah data 30\% tersebut berasal dari 25 Pengusaha kos yang berasal dari daerah Gunungpati dan 5 dari pengusaha kos di Tembalang. Hasil penjumlahan data di atas sangatlah mengagetkan mengingat banyaknya jumlah wajib pajak yang terdaftar namun untuk pengetahuan seputar pajak kos masih sangat minimal.Selain itu juga, peneliti ingin mengetahui partisipasi wajib pajak terhadap keberadaan pajak kos. Hal itu dapat dilihat pada gambar 7 pie chart ini.

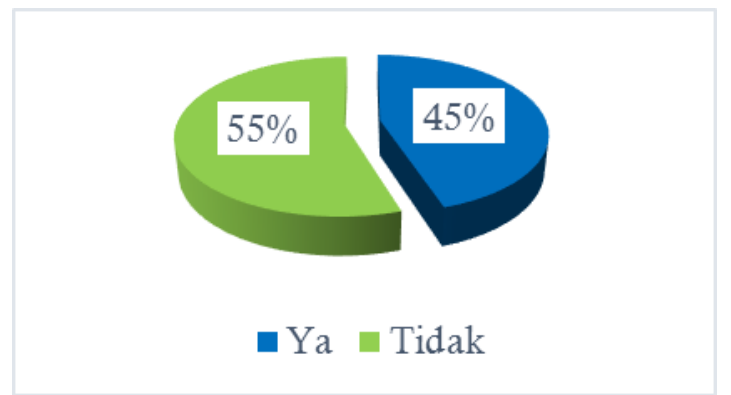

Gambar 7.Pie Chart Pengusaha Kos hadir pada acara sosialisasi yang dilaksanakan oleh Petugas Pajak

Sumber: Data primer diolah, 2017

Pengusaha kos yang hadir pada acara sosialisasi yang dilaksanakan oleh petugas pajak adalah sejumlah $45 \%$, data $45 \%$ tersebut berasal dari 29 pengusaha kos yang berasal dari Gunungpati dan 16 dari pengusaha kos di Tembalang. Sementara untuk pengusaha kos yang tidak hadir pada acara sosialisasi yang dilaksanakan oleh petugas pajak adalah adalah sejumlah 55\%, data 55\% tersebut berasal dari 41 pengusaha kos yang berasal dari daerah Gunungpati dan 14 dari pengusaha kos di Tembalang. Sehingga wajar saja jika wajib pajak tidak mengetahui mengenai adanya pajak untuk rumah kos yang lebih dari 10 kamar karena tingkat partisipasi terhadap pajak kos yang masih kurang.

Selain melihat dari segi wajib pajak, peneliti juga melihat dari kinerja yang dilakukan oleh petugas pajak menurut pandangan wajib pajak. Dibawah ini merupakan gambar pie chart mengenai ketepatan sasaran dari acara sosialisasi.

Pie chart gambar 8 membahas tentang ketepatan sasaran dari acara sosialisasi yang dilaksanakan oleh petugas pajak menurut pandangan wajib pajak. Nilai persentase untuk ketepatan sasaran dari acara sosialisasi yang dilaksanakan oleh petugas pajak adalah sejumlah $23 \%$, dari data $23 \%$ tersebut berasal dari 12 pengusaha kos yang berasal dari Gunungpati dan 11 dari pengusaha kos di Tembalang. Sementara untuk pengusaha kos yang merasa bahwa acara sosialisasi yang 
dilaksanakan oleh petugas pajak yang belum tepat sasaran adalah sejumlah $77 \%$, data $77 \%$ tersebut berasal dari 58 pengusaha kos yang berasal dari daerah Gunungpati dan 19 dari pengusaha kos di Tembalang. Sehingga dari hal ini bisa kita lihat bahwa tidak ada sinkronisasi maupun kerjasama antara wajib pajak dan petugas pajak dengan baik. Hal inilah yang menjadi faktor penghambat dalam peningkatan pemungutan pajak kos.

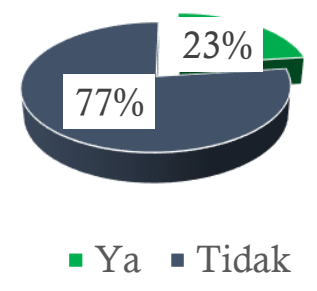

Gambar 8.Pie Char tketepatan sasaran dari acara sosialisasi

Sumber: Data primer diolah, 2017

Selain melihat dari segi wajib pajak, peneliti juga melihat dari kinerja yang dilakukan oleh petugas pajak menurut pandangan wajib pajak. Dibawah ini merupakan gambar pie chart mengenai manfaat dari pelaksanaan sosialisasi untuk wajib pajak.

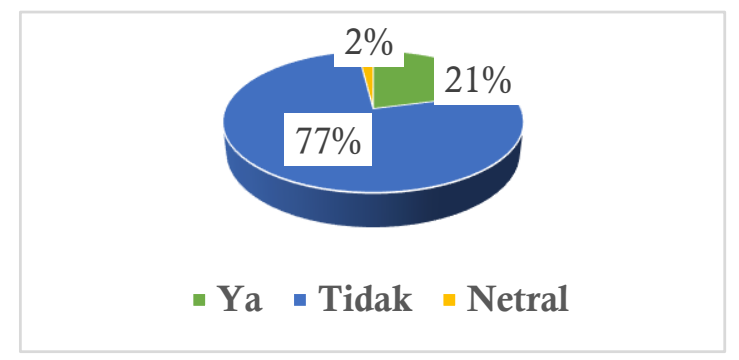

Gambar 9. Pengusaha kos memperoleh manfaat dari pelaksanaan sosialisasipajak kos Sumber: Data primer diolah, 2017

Pie chart di atas membahas tentang manfaat dari pelaksanaan sosialisasi yang dilaksanakan oleh petugas pajak menurut pandangan wajib pajak. Hasil persentase untuk manfaat dari acara sosialisasi yang dilaksanakan oleh petugas pajak adalah sejumlah $21 \%$, data $21 \%$ tersebut berasal dari 13 pengusaha kos yang berasal dari Gunungpati dan 8 dari pengusaha kos di Tembalang. Sementara untuk pengusaha kos yang tidak memperoleh manfaat dari acara sosialisasi yang dilaksanakan oleh petugas pajak adalah sejumlah $77 \%$, dari data $77 \%$ tersebut berasal dari 55 pengusaha kos yang berasal dari daerah Gunungpati dan 22 dari pengusaha kos di Tembalang. Selain itu juga terdapat wajib pajak yang berasal dari Gunungpati yang beranggapan netral sebesar $2 \%$ dengan jumlah 2 wajib pajak. Peneliti juga melihat pengetahuan dari wajib pajak terkait mengenai sanksi jika tidak membayar pajak yang dapat dijelaskan pada gambar pie chart ini.

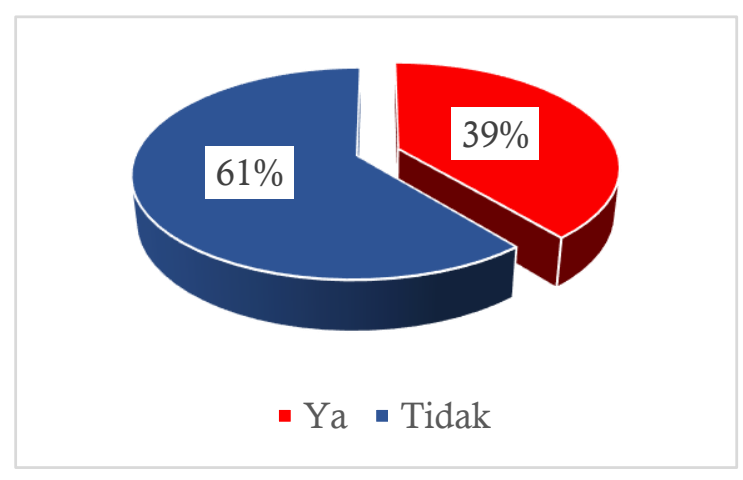

Gambar 10. Pengusaha Kos mengetahui sanksi jika tidak membayar pajak kos Sumber: Data primer diolah, 2017

Pie chart di atas membahas tentang pengetahuan wajib pajak dalam mengetahui sanksi yang didapatkan jika tidak membayar pajak tepat waktu. Wajib pajak yang mengetahui sanksi yang didapatkan jika tidak membayar pajak adalah sejumlah 39\%, data $39 \%$ tersebut berasal dari 23 pengusaha kos yang berasal dari Gunungpati dan 16 dari pengusaha kos di Tembalang. Sementara untuk pengusaha kos yang tidak mengetahui sanksi yang didapatkan jika tidak membayar pajak adalah sejumlah $61 \%$, dari data $61 \%$ tersebut berasal dari 47 pengusaha kos yang berasal dari daerah Gunungpati dan 14 dari pengusaha kos di Tembalang.

Selain meneliti terkait pengetahuan wajib pajak, peneliti juga ingin melihat seberapa jauh pengetahuan terhadap pajak kos. Dibawah ini merupakan gambar pie chart mengenai 
pengetahuan wajib pajak mengenai prosedur dalam membayar pajak kos.

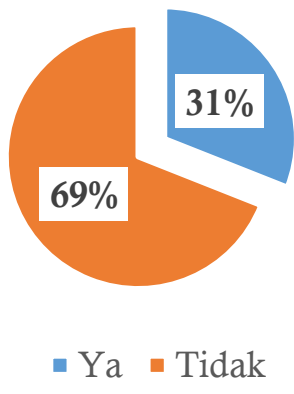

Gambar 11. Pengusaha Kos mengetahui prosedur dalam membayar pajak

Sumber: Data primer diolah, 2017

Pie chart pada gambar 11 membahas tentang pengetahuan mengenai prosedur dalam membayar pajak kos oleh wajib pajak. wajib pajak yang mengetahui prosedurnya adalah sejumlah $31 \%$, data $31 \%$ tersebut berasal dari 14 pengusaha kos yang berasal dari Gunungpati dan 17 dari pengusaha kos di Tembalang. Sementara untuk pengusaha kos yang tidak mengetahui mengenai prosedur dalam membayar pajak kos adalah sejumlah $69 \%$, data $69 \%$ tersebut berasal dari 56 pengusaha kos yang berasal dari daerah Gunungpati dan 13 dari pengusaha kos di Tembalang.Selain itu, peneliti juga ingin melihat seberapa jauh pengetahuan wajib pajak mengenai Peraturan Daerah mengenai pajak hotel khususnya pajak kos. Dibawah ini merupakan gambar pie chart mengenai pengetahuan wajib pajak untuk PERDA pajak hotel.

Pie chart gambar 12 membahas tentang pengetahuan wajib pajak terhadap PERDA Kota Semarang nomor 3 tahun 2011 tentang pajak hotel. Wajib pajak yang mengetahui PERDA Kota Semarang tersebut adalah sejumlah $25 \%$, data $25 \%$ tersebut berasal dari 11 pengusaha kos yang berasal dari Gunungpati dan 14 dari pengusaha kos di Tembalang. Sementara untuk pengusaha kos yang merasa bahwa acara sosialisasi yang dilaksanakan oleh petugas pajak yang belum tepat sasaran adalah sejumlah $75 \%$, data $75 \%$ tersebut berasal dari 59 pengusaha kos yang berasal dari daerah
Gunungpati dan 16 dari pengusaha kos di Tembalang.

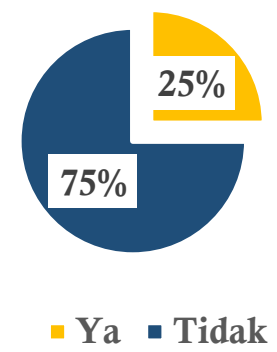

Gambar 12. Wajib Pajakmengetahui PERDA Kota Semarang nomor 3 tahun 2011 tentang pajak hotel

Sumber: Data primer diolah, 2017

Beberapa wajib pajak mempunyai kepatuhan yang buruk dengan tidak membuat dan menyampaikan laporan kegiatan usaha secara periodik, baik laporan bulanan maupun tahunan. Hal yang memprihatinkan adalah wajib pajak semacam ini berjumlah paling banyak dari seluruh wajib pajak terdaftar. Ketidakpatuhan wajib pajak yang lebih buruk dari sekedar tidak menyampaikan SPT tepat waktu adalah ketidakpatuhan dengan sengaja hanya melaporkan sebagian kegiatan usaha.

Sesuai ketetapannya, wajib pajak rumah kos harus membayar pajak setiap satu bulan, dengan tarif sebesar $10 \%$ dari penghasilannya.

Tetapi dari hasil wawancara banyak wajib pajak rumah kos yang menunggak untuk pembayarannya dan baru disetorkan langsung dalam hitungan satu tahun. Para wajib pajak tersebut mempunyai berbagai alasan, alasan tersebut seperti tidak mempunyai waktu untuk membayarnya setiap dalam hitungan satu bulan. Semua yang dilakukan oleh wajib pajak dalam menggelapkan utang pajak dapat dipahami, karena manusia diciptakan Tuhan sangat menyukai harta benda dan akan berusaha sekuat tenaga agar harta benda yang dimilikinya tidak beralih kepada pihak lain. Oleh karenanya perlu diberikan sanksi tegas agar naluri tersebut tidak melanggar kewajiban berbangsa dan bernegara. Hal tersebut didukung 
oleh data pie chart dibawah ini yang membahas tentang pengusaha kosmembayar pajakkos. Hasil persentae untuk pengusaha kosyang membayar pajak kos adalah sejumlah $24 \%$, data $24 \%$ tersebut berasal dari 9 pengusaha kos yang berasal dari Gunungpati dan 15 dari pengusaha kos di Tembalang. Sementara untuk pengusaha kos yang tidak membayar pajak kos adalah sejumlah $76 \%$, data $76 \%$ tersebut berasal dari 61 pengusaha kos yang berasal dari daerah Gunungpati dan 15 dari pengusaha kos di Tembalang.

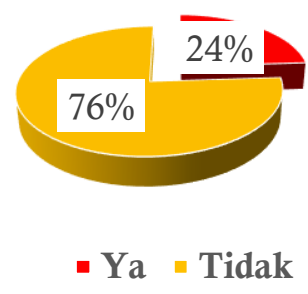

Gambar 13. Pengusaha Kosmembayar pajakkos Sumber: Data primer diolah, 2017

Membayar pajak adalah kewajiban setiap warga negara. Tapi, ternyata tidak semudah yang dibayangkan. Wajib pajak rumah kos yang merasa enggan untuk mengantri dan wajib pajak mengaku bahwa masih banyak pekerjaan lain yang akan dikerjakan, karena wajib pajak tidak mempunyai banyak waktu jadi lebih memilih pembayaran setiap satu tahun. Faktor utama yang menghambat penerapan pajak hotel kategori rumah kos tersebut adalah waktu, karena banyak wajib pajak yang tidak mempunyai waktu untuk menyetorkan pajaknya sendiri setiap satu bulan, sehingga banyak wajib pajak yang menyetorkan pajaknya langsung dalam hitungan satu tahun. Hal tersebut sangat menyulitkan pihak BAPENDA dalam menghitung dan menyusun laporan perpajakannya, sehingga menghambat kinerja BAPENDA tersebut. Hal ini juga didukung melalui data pie chart yang berasal dari responden yang terdapat dibawah ini.

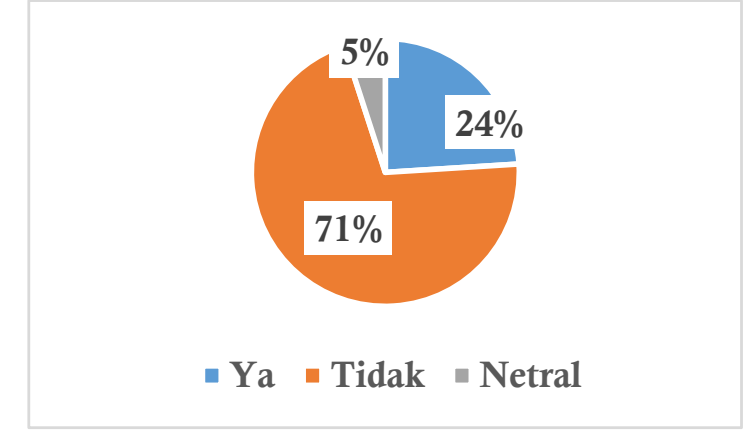

Gambar 14.Jangka waktu pembayaran untuk pajak kos terhadap kesanggupan Wajib Pajak Sumber: Data primer diolah, 2017

Pie chart di atas membahas tentang jangka waktu pembayaran untuk pajak kos terhadap kesanggupan wajib pajak. Hasil persentase dalam melihat jangka waktu terhadap kesanggupan wajib pajak dalam melakukan pembayaran untuk pajak kos adalah sejumlah $24 \%$, data $24 \%$ tersebut berasal dari 7 pengusaha kos yang berasal dari Gunungpati dan 17 dari pengusaha kos di Tembalang.

Sementara untuk pengusaha kos yang tidak sanggup adalah sejumlah $71 \%$, data $71 \%$ tersebut berasal dari 58 pengusaha kos yang berasal dari daerah Gunungpati dan 13 dari pengusaha kos di Tembalang. Selain itu, terdapat wajib pajak yang berlaku netral sebesar 5\% di daerah Gunungpati dengan jumlah 5 wajib pajak.

Strategi yang sebelumnya dilaksanakan oleh BAPENDA Kota Semarang selain memiliki tugas untuk mengembangkan juga sebagai pengawal berjalannya proses implementasi peraturan daerah pajak hotel di Kota Semarang. Sosialisasi sebagai upaya penting dalam hal peningkatan kesadaran wajib pajak. Menurut Binambuni (2013) frekuensi pemberian sosialisasi yang dilakukan secara efektif dan tata cara pemberian sosialisasi yang mudah dipahami akan meningkatkan kepatuhan wajib pajak. Sosialisasi dan pemahaman perpajakan merupakan hal yang penting bagi masyarakat yang masih belum dapat memahami 
pajak itu sendiri. Pemahaman wajib pajak mengenai perpajakan akan membuat sistem self assessment berjalan sesuai tujuan Direktorat Jendral Pajak. Peningkatan kemampuan komunikasi dari Petugas BAPENDA menjadi penting karena dalam usaha untuk meningkatkan mutu sosialisasi beserta dengan penyampaian informasi Peraturan Daerah yang jelas harus didasari oleh kemampuan komunikasi dari Petugas BAPENDA sendiri. Petugas BAPENDA harus mengetahui setiap karakteristik dari tiap pengusaha kos.

Menurut Supadmi (2012) yang menjelaskan bahwa untuk meningkatkan kepatuhan wajib pajak dalam memenuhi kewajiban perpajakannya kualitas pelayanan harus ditingkatkan oleh aparat pajak. Pelayanan yang berkualitas harus diupayakan dapat memberikan $4 \mathrm{~K}$ yaitu keamanan, kenyamanan, kelancaran, dan kepastian hukum yang dapat di pertanggung jawabkan.Alternatif strategi diprioritas ketiga adalah peningkatan penyebaran informasi pajak kos melalui media massa. Seperti yang disampaikan Kasubid Pendaftaran dan Pendataan BAPENDA Kota Semarang bahwa kurangnya penyebaran informasi ke masyarakat membuat pengetahuan masyarakat terhadap PERDA pajak hotel ini masih tergolong rendah.Selain itu, peningkatan kepatuhan dan ketepatan waktu petugas BAPENDA dan wajib pajak dalam mematuhi Peraturan Daerah tentunya cukup penting. Hal tersebut sangat berkaitansejalan dengan pendapat dari salah satu wajib pajak yang menyebutkan bahwa dalam melaksanakan tugas baik di lapangan maupun di dalam kantor merupakan salah satu aspek yang cukup krusial. Hal tersebut membuat kita sebagai wajib pajak dapat menilai seberapa besar tingkat profesionalisme petugas pajak. Semakin tinggi tingkat profesionalisme dapat berdampak kepada semakin tinggi pula tingkat kepatuhan wajib pajak dalam membayar pajak kos.

\section{SIMPULAN}

Berdasarkan hasil analisis dan pembahasan implementasi Peratuan Daerah
Kota Semarang nomor 3 tahun 2011 tentang pajak hotel kategori usaha rumah kos ditemukan kendala-kendala yang dialami dalam mengimplementasikan Peraturan Daerah nomor 3 tahun 2013 tentang pajak hotel kategori usaha rumah kos yang diantaranya Peraturan Daerah, Eksistensi wajib pajak yang tinggi untuk menolak karena tarifnya dinilai terlalu tinggi, pemahaman wajib pajak terkait kebijakan peraturan daerah pajak hotel kategori usaha rumah kos, kepatuhan wajib pajak dalam membayar pajak kos, dan waktu dalam membayar pajak yang dinilai terlalu singkat.

\section{DAFTAR PUSTAKA}

Afifah, Lailatul Fitria. (2015). Respon Wajib Pajak terhadap Pajak Daerah Kategori Rumah Kos di Kota Malang. Disertasi. Malang: Universitas Muhammadiyah Malang.

Berutu, Dian A. (2013). Persepsi Keadilan Pajak Terhadap Perilaku Kepatuhan Wajib Pajak Orang Pribadi (WPOP). Skripsi. Semarang: Fakultas Ekonomi dan Bisnis UNDIP.

Edward III, George C. (1980). Implementing Public Policy. Washington: Congressional Quarterly Press.

Guilford, J. P. (1956). Fundamental Statistics in Psychology and Education. New York: Mc Graw-Hill Book Co. Inc.

Ilyas, B. Irawan dan Waluyo. (2000). Perpajakan Indonesia. Jakarta: Salemba Empat.

Kasper, Matthias, dkk. (2015). Tax policy and the news: An empirical analysis of taxpayers' perceptions of tax-related media coverage and its impact on tax compliance. Journal of Behavioral and Experimental Economics, Volume 54 Page 58-63 Austria: University of Vienna.

Mardiasmo. (2002). Perpajakan. Edisi Revisi, Cetakan Kesembilan. Jakarta: Andi.

Mukhtar. (2013). Metode Praktis Penelitian Deskriptif Kualitatif. Jakarta: Referensi (GP Press Group).

Obeidat, Mohammed Ibrahim Sultan. (2009). How Taxpayers Perceive the Efficiency of Jordanian Tax Systems According to the Keynesian Perspective of Tax Efficiency. Journal of Economic and Administrative Sciences, Volume 25 No. 2. Page 79-109 Canada: Universite Laval.

Permata, Rachellaura Lintang. (2016). Persepsi Wajib Pajak tentang Pajak Rumah Kos di Kabupaten Tulungagung Jawa Timur. Skripsi. 
Surabaya: Fakultas Ekonomi Universitas Negeri Surabaya.

Rachmawati, Riska, dkk. (2015). Analisis FaktorFaktor Penghambat Penerapan Pajak Hotel Kategori Rumah Kos yang Terdaftar pada Kantor Dinas Pendapatan Daerah Kota Palembang. Jurnal Akuntansi, Palembang: STIE Multi Data Palembang.

Resmi, S. (2011). Perpajakan Teori dan Kasus. Jakarta: Salemba Empat.

Supadmi, Ni Luh. (2012). Meningkatkan Kepatuhan Wajib Pajak Melalui Kualitas pelayanan. Jurnal Akuntansi dan Bisnis, Volume 4 No.2. Bali: Fakultas Ekonomi Universitas Udayana.

Suryarini, T., \& Tarmudji, T. (2012). Pajak di Indonesia. Yogyakarta: Graha Ilmu.
Suseno, deky A. (2015). Pengembangan daerah berdasarkan tipologi pertumbuhan ekonomi dan ketimpangan sektor di wilayah kedung sepur, 8(1). https://doi.org/10.15294/jejak.v7i1.Journal. (2004). Undang - Undang Republik Indonesia No. 32 Tahun 2004 tentang Pemerintahan Daerah.

(2009). Undang - Undang Republik Indonesia No. 28 Tahun 2009 tentang Pajak Daerah dan Retribusi Daerah.

(2011). Peraturan Daerah Kota Semarang No. 3 Tahun 2011 tentang Pajak Daerah dan Retribusi

Daerah. 